\title{
Ed Blissett
}

\section{University of Hertfordshire}

Fatally Divided?

\section{An analysis of the role micro-political divisions played in the unions' loss of the 1986-87 News International dispute.}

\section{Introduction}

On the $5^{\text {th }}$ February 1987 the Society of Graphical and Allied Trades (SOGAT) National Executive Committee (NEC) voted 23 to 9 to end its dispute with News International Limited. One day later the National Graphical Association (NGA) National Council (NC) followed suit and ended its industrial action. These decisions brought to a close one of the most bitter and acrimonious industrial disputes of the twentieth century.

The dispute had lasted over a year, and had seen one of the final deployments by the British union movement of mass picketing and secondary industrial action. These tactics drew a ruthless response from both the employer and the State. News International dismissed all 5,500 union members who went on strike, and successfully sought injunctions against the unions for taking, what had recently become, unlawful secondary action.

When the print unions refused to stop their secondary action, the High Court sequestrated ${ }^{1}$ their assets, having found them in contempt of court. Against the mass picketing the Metropolitan Police deployed both mounted and anti-riot officers to ensure access to the Wapping print works. At the same time night curfews were frequently imposed on the area around the Wapping plant, where road regulations were also regularly waived in order to assist lorries exiting the site.

The loss of the dispute also heralded an undermining of the extensive control that both the NGA and SOGAT had enjoyed for more than half a century over the newspaper industry's labour processes, whereby the print unions decided who filled non journalistic vacancies ${ }^{2}$; how many

${ }^{1}$ Sequestration involves the seizing of the property and financial assets of an organisation by officers of the Court

2 Prior to 1986 both SOGAT and the NGA had pre-entry closed shop agreements at News International and with all other national newspapers,. This meant that only current members of the 
production staff worked on a given shift; and which workers were allowed to undertake the different tasks in the production and preproduction process. This extraordinary level of control of the labour process was allied to comparatively high wages which the NGA and SOGAT had secured for their skilled and semi-skilled newspaper members. These earnings, along with the extensive control of the labour process, had been attained by the print unions engaging regularly in highly effective industrial action.

There has been a wide variety of explanations as to why the unions' action at News International in 1986-87 was unsuccessful. Many authors have asserted that the dispute was unwinnable, whatever tactics the unions had deployed (Melvern, 1986; Gennard, 1990; Gennard and Bain, 1995; Dean, 2007). This, they argue, was owing to the combination of technological advancements and the hostile political and institutional environment in which the unions were operating (Melvern, 1986; Gennard, 1990; Gennard and Bain, 1995; Dean, 2007).

Other scholars (Richardson, 2003; Cockburn, 1991; Bain, 1998; Cohen, 1990) have taken a different view, focusing on tactical errors and divisions within and between the printing unions, which adversely affected their chances of success. However, these authors disagree over the reasons for inter and intra-union disunity and policy mistakes. Richardson (2003) and Bain (1998) assert that long-running political, occupational and geographical conflicts created serious rifts within SOGAT and between the two print unions. Cockburn (1991) differs, asserting instead that gender segregation and misogyny caused disunity within the print unions, which undermined the dispute. While Cohen (1990) insists that the defeat can be broadly attributed to the failure of SOGAT and the NGA to continue with secondary industrial action after the sequestration of their assets. Within all of these analyses the role played by micro-political factors, such as personal friendships, enmities and loyalties are occasionally noted (Bain, 1998; Richardson, 2003), but are not credited with significantly contributing to the loss of the dispute.

appropriate union could fill any vacancy. At News International there was also an agreement that the unions would decide on a single applicant, from among their appropriately skilled unemployed members, to fill a vacancy. 
This article, while accepting that institutional contextual factors played a significant part in the unions defeat, puts forward a different hypothesis: that micro-political divisions, both within and between the print unions, contributed significantly to the unions' loss of 1986/87 News International dispute. Specifically the article argues that the long-term dysfunctional relationships between the News International senior lay activists and the SOGAT General Secretary, Brenda Dean, and the personal, as opposed to political or industrial, enmity between Brenda Dean and NGA General Secretary, Tony Dubbins, combined to contribute to the unions' defeat. Finally the article asserts that Dean's personal loathing of Robert Maxwell ${ }^{3}$, and her considerable regard for Rupert Murdoch, significantly affected how she dealt with News International before and during the dispute.

In order to test this hypothesis extensive research was undertaken, involving in-depth, semi-structured, interviews with print union full-time and lay officers. Some of this fieldwork was undertaken as part of a wider study of policy-making in the British and Australian printing and telecommunication unions (Blissett, 2014). The majority of the original interviews were conducted in the mid-1990s, with follow-up interviews taking place in the late 2000s.

As a former senior officer of two British trade unions and a lay activist in a third ${ }^{4}$ I understood the reticence of union activists and officers to admit to external third parties how micro-political influences, particularly personal enmities, affected their behaviour and policy choices. Drawing upon personal experience, I was also aware that union officials needed to feel comfortable that any confidences they disclosed would not be breached. It was for this reason that a longitudinal study was entered into, that involved 3 or 4 interviews with key policy makers, spaced over a number of years. Additionally I knew that many union officers became very guarded when they were being tape-recorded. There were two

\footnotetext{
${ }^{3}$ The owner of Mirror Group Newspapers from 1984-1991

${ }^{4}$ I worked as a National Officer for the Banking Insurance and Finance Union from 1989-1994.

Subsequently I was employed as an Organising Officer, Senior Organiser, London Regional Secretary and a National Officer of the GMB Union from 1997-2009. Between1985-1989 I had been a Transport and General Workers Union (TGWU) Branch Secretary and Regional Trade Group delegate. I was also a member of the TGWU Broad Left faction. After starting work at the Banking, Insurance and Finance Union (BIFU) I became a Branch Secretary and London Regional Council member of Association of Professional, Executive, Clerical and Computer Staff (APEX), which merged in 1989 with the GMB Union.
} 
primary reasons for this apprehension. First, they feared that assurances of anonymity would be broken and their interviews played back to external, or internal, third parties. Second, if an interview was tape recorded, a participant would know that simply denying that they had made, for example, highly critical remarks about senior colleagues, would be untenable.

For these reasons short-hand notes were made of all interviews, with note-taking ceasing when the nature of the discussions became sensitive. Whilst this method of recording did not guarantee a verbatim record of each interview, it did get extremely close to doing so, while avoiding interviewee reticence that often comes with tape-recoding.

In what follows the nature of micro-political influences that operated inside the print unions, prior to and during the dispute, are outlined. How different dysfunctional personal relationships affected the print unions' conduct of the dispute and its outcome is also considered. Finally this paper's findings are juxtaposed with previous explanations for the unions defeat.

\section{Micro-political divisions in SOGAT, before the dispute}

At the beginning of 1985 the relationship between the newly elected SOGAT General Secretary, Brenda Dean, and the leaders of the powerful London national newspaper chapels, who had opposed her election, was one of mutual distrust and animosity. Interviewees all agreed that this enmity and suspicion was particularly virulent between Dean and the News International production chapel officers. Such was the level of animosity that one then senior SOGAT officer characterised their relationship as one of "total mutual loathing". This fissure was significant, as, for historical reasons, SOGAT represented the vast bulk of not only the semi-skilled and white-collar staff at News International, but also many skilled production workers.

After Dean's election the already highly autonomous production chapels, sought even greater negotiating independence. The production chapels' Imperial Fathers of Chapel (IFoCs) and Fathers of Chapel (FoCs) (lay officer posts equivalent to a convenor and shop stewards in non printing unions) had historically conducted a great deal of collective bargaining themselves, now started to conduct discrete negotiations with 
management over a potential move to the planned News International production plant at Wapping. This was the case even though the negotiations were meant to be headed by the SOGAT National Officer for national newspapers, Bill Miles.

The production chapels' belief in their own negotiating ability had been strengthened by their victory in the year-long dispute at Times Newspapers, which had ended in 1979. This success was achieved in the face of national union advice that they should be more willing to compromise. The strike, which had been called over proposed staffing cuts and single keystroking ${ }^{5}$, was finally settled by Thomsons Newspapers Limited in order to facilitate its sale of the Times Newspapers Group to Rupert Murdoch.

The production chapels' 'unofficial' negotiations over the move to Wapping annoyed not only Dean, but also the non-production FoC's at News International, and the provincial branches. The relationship between these groups was already strained following the pivotal role News International production chapels played in derailing a national union policy, entitled Programme for Action, which proposed that SOGAT members were more flexible in enforcing demarcation lines, in return for job-security agreements. The national newspaper production chapels' implacable refusal to implement Programme for Action had incensed many NEC members from outside London who had, often with great difficulty, persuaded their branches to adopt the policy. It also caused a rift inside SOGAT's News International structure where the non-production chapel officers had been prepared to implement the policy.

This divergence in approach led to what interviewees described as a number of 'very heated' and 'highly personal' arguments between the respective News International chapels' officers. This tension was further exacerbated in 1983 when some elements of the non-production chapels tacitly supported Dean in her successful bid to become SOGAT President.

\footnotetext{
${ }^{5}$ In 1978/79 there was a twelve month strike at Times Newspapers Limited which was called over the employers wish to allow their journalists to directly enter copy, a process known as 'single keystroking' (see Blissett, 2014; Gennard, 1990).
} 
While these events are critical in explaining the disunity that afflicted SOGAT in the mid-1980s, the union's deep internal conflict went back further and was not driven by gender, occupational, political or geographical disagreements, but by personal animosity. Dean herself substantiates this argument (Dean, 2007) when recalling how rude the London newspaper delegates were to her when they first met in 1968 at the SOGAT Biennial Conference. What is unclear in her account (Dean, 2007:15) is why she believes these delegates were so hostile. Interviewees from both camps were also vague as to why there was such an instant animosity. Those antagonistic to Dean cite the fact that she had a "superior" or "prim" manner and had not performed the role of a Mother of Chapel (MoC) $)^{6}$. Dean's supporters, and some authors (Cockburn, 1991; Dawson 2010), instead highlighted the London FoC's sexism and regional prejudice. However, when pressed, interviewees conceded that other women from SOGAT's provincial branches did not suffer the same level of hostility.

A senior Dean supporter, who unusually remained on good terms with the News International activists, stated that Dean took an instant dislike to what she perceived as the "crudity and arrogance" of the London FoC's. He further asserted that they "sensed her disapproval" and reacted by becoming "more boorish". Significantly, all the interviewees who had first-hand knowledge of these initial encounters, agreed that the hostility did not solely stem from political, geographic or gender tensions, but instead were more subtle and micro-political in nature.

As Brenda Dean rose rapidly to national prominence in SOGAT, firstly as the Branch Secretary of the large Manchester branch, then President and finally General Secretary, her poor relationship with the London newspaper activists deteriorated further. According to interviewees', part of the reason for this worsening in relations was Dean's less confrontational approach when, as Manchester Branch Secretary, she and the London FoCs negotiated with national newspaper companies. Yet these same interviewees also highlight problems on the SOGAT NEC, where Dean's active support of the London Women's branch in a

\footnotetext{
${ }^{6}$ Brenda Dean had not been a local union representative, known in the print industry as a Father/Mother of Chapel. Instead she had worked initially as a secretarial worker in a printing company and then as a secretary in SOGAT's Manchester branch, before becoming a branch officer and then Manchester Branch Secretary (Dean 2007).
} 
demarcation dispute with the London Central branch at Format International, greatly angered the national newspaper FoCs. The dispute sparked a major internal conflict, with the London Central branch refusing to remit membership subscriptions, whilst also launching a legal action against SOGAT's NEC. Dean supported the successful call for the national union to respond by removing London Central branch's delegates from the NEC, barring the branch from the union's Bi-ennial Conference, and issuing its own legal proceedings (See Blissett 2014; Gennard and Bain, 1995; Dean, 2007).

After this conflict was resolved in 1978, the tension between Dean and the London national newspaper activists escalated further when she stood and defeated their nominee, George Willoughby, along with ten other candidates, for National President in 1983. In doing so Dean allegedly gained support from members of the non-production chapels at News International, which infuriated the production FoCs and added fuel to their own internal conflict with the non-production chapels.

Dean's relationship with the News International production chapels soured even further when, after Bill Keys ${ }^{7}$ announced his early retirement in 1984, Dean won the subsequent election for General Secretary. The overwhelming consensus before the election was that Keys would be succeeded by a candidate from London, a not unreasonable assumption given that all the previous SOGAT and National Society of Operative Printers and Assistants (NATSOPA) ${ }^{8}$ General Secretaries, had been members of the London branches.

However, a group of SOGAT North Western branch secretaries, many of whom were also NEC members, persuaded Dean to accept a nomination for General Secretary. They believed that Dean could attract votes across traditional regional and occupational divisions, because of what many of them described as her "personal charm", as opposed to any particular ideological qualities. Significantly, in what was a predominantly male union, they also gambled that she would not lose votes because of her gender. Dean's success, in an election contested by twelve candidates, was a vindication of their views. It was also a

\footnotetext{
${ }^{7}$ Bill Keys was the SOGAT General Secretary from 1975-1985.

${ }^{8}$ NATSOPA merged with National Union of Printing Bookbinding and Paper Workers (NUPBPW) to form SOGAT in 1966. NATSOPA then seceded from SOGAT in 1972 before amalgamating with SOGAT again in 1982.
} 
considerable shock and disappointment to the News International FoCs who had so vehemently opposed her.

It was against this background of longstanding animosity that Dean began her tenure as General Secretary. She was immediately faced with a series of industrial disputes, involving the national newspapers chapels, with whom she had such a poor relationship. The most prominent of these disputes was that at Mirror Group Newspapers. For Dean this entailed dealing with Robert Maxwell, who, as one interviewee observed, she "totally hated". The animosity that Dean felt towards Maxwell went back decades and centred not on industrial or political disagreements, but on Dean's own personal repugnance for Maxwell (Dean 2007:58). This dislike stemmed from Maxwell's behaviour towards Dean during the time she was SOGAT President. Interviewees relate how much Dean disliked his 'hectoring and condescending' approach towards her, while Dean herself focuses on how 'dishonourably' he had behaved towards her in negotiations (Dean, 2007:60).

The dispute at Mirror Group Newspapers in 1984 was overtly over the introduction of new technology and redundancies. As Dean stated, the underlying reason for this and many other disputes with Maxwell's was his "bullying" management style (Dean, 2008:62). During the Mirror Group Newspapers dispute interviewees describe how Dean became angry and exasperated with Maxwell's "erratic and offensive behaviour". In response Dean tried to bring commercial pressure to bear on Maxwell in order to force him to reach a settlement. To this end she contacted Maxwell's then great rival in the British tabloid newspaper market, Rupert Murdoch, to persuade him to print more copies of The Sun, and run an aggressive advertising campaign to get Daily Mirror readers to switch to buying The Sun. Dean's strategy was to be overtaken by events, with an agreement being reached with Mirror Group Newspapers prior to any intervention by Murdoch, but her personal contact with him was to have far-reaching consequences.

Dean had intended that her request for assistance from Murdoch would be confidential. This proved to be a forlorn hope, with senior SOGAT Mirror Group and News International activists swiftly discovering that she had made contact. The reaction of the News International production FoCs was, predictably, negative. They had always felt that Dean was too 
close to management and her actions in this case reinforced their belief. It also provided a further reason not to involve the national union in their negotiations over a move to Wapping.

By 1985 these negotiations had become focused on the substantial staff cutbacks that the company was demanding prior to the introduction of direct text inputting ${ }^{9}$ by journalists and the installing of new printing presses at Bouverie Street and Wapping. At that time News International claimed that the Wapping site would be used for the production of a new title, The London Post, and for the printing of some current titles including The News of the World.

It was during this period that the rumours grew stronger that Wapping was being equipped to house the whole of News International's English operations. Whilst this speculation was forcefully denied by management it was given substance by activists from the SOGAT Revisers and Ink Roller Manufacture Auxiliaries branch (RIRMA) branch and the News International Amalgamated Union of Engineering Workers (AUEW) engineering chapel, who stated that they had received information from workers 'fitting out' Wapping that the plant was being prepared to produce all the company's titles and that an alternative workforce was being hired.

The RIRMA branch leadership organised a meeting in June 1985, where, they stated, they would share the evidence. All the News International chapels were invited to attend, yet no officer from any of the News International production chapels accepted the invitation (Blissett, 2014; Gennard and Bain, 1995). The reasons why the production chapels refused to attend is mired in controversy. Some interviewees state that the SOGAT and NGA production chapels' inherent elitism led them to ignore any information provided by what they viewed as lowly maintenance chapel activists. However, as many interviewees acknowledged, there were also micro-political factors at work. Specifically there was ill feeling towards the RIRMA branch officers from the pre-press and production chapel counterparts over their "failure to stop" some RIRMA members voting for Dean in the General Secretary's election. These tensions were magnified further when a

\footnotetext{
${ }^{9}$ Direct text inputting allowed journalists and editors to place copy into the newspaper without it passing through the hands of the Compositors.
} 
series of heated arguments took place between the respective IFOCs and FOCs over RIRMA members support for Dean, after her election victory. These disagreements led to a great deal of simmering animosity between the parties.

Dean, unlike the production chapel IFoC's and FoC's, did met the RIRMA branch officers to discuss their concerns about Murdoch's plans for the Wapping plant. She was sufficiently concerned by the evidence produced to call a meeting of all The Sun and the News of the World IFoCs and FoCs. The production chapels' officers did attend this meeting, but were sceptical about the evidence. They did though agree that the union should, along with the NGA, seek an urgent meeting with News International.

At that meeting the company gave categorical assurances that the activity at Wapping was owing to the company preparing to launch The Post, and that negotiations over any transfer of location for The Sun and the News of the World would be completed in the next couple of months. The unions were also told that Rupert Murdoch would meet them at the end of September 1985. In addition to this meeting the print unions also held discussions with the Electrical, Electronics and Plumbing Trade Union (EETPU), whose representatives explicitly stated that their members working at Wapping were only installing and testing equipment. Although still concerned about the activities of the company at Wapping, the unions accepted their reassurances and those from EETPU and did not take any unofficial industrial action. Significantly, it was Brenda Dean who spoke most powerfully in favour of accepting the assurances given by Murdoch and the EETPU.

As events were to prove News International and the EETPU's assurances were nothing but hollow promises (Hammond, 1992). Unbeknown to the print unions, News International and the EETPU had been engaged for some months in negotiations over the union providing an alternative workforce for Wapping, whilst also negotiating a no-strike, single-union recognition agreement ${ }^{10}$. These discussions continued in secret, while the SOGAT and NGA chapels continued to engage in talks over a move of their members to Wapping.

${ }^{10}$ Eventually no agreement was reached with the EETPU by News International. 


\section{Micro-political divisions between Dean and Dubbins, before the dispute}

In convening the meeting with News International in the summer of 1985 Dean had invited her opposite number at the NGA, Tony Dubbins to attend. He did so and was extremely concerned at the evidence provided by the RIRMA and the AUEW branch. There was though, according to some of those present, a "clear distrust" between the two General Secretaries at these meetings. This wariness reflected what one SOGAT officer described as a "palpable dislike" that existed between them.

Dean herself has admitted that by this stage she had a very difficult personal, as well as professional, relationship with Dubbins. These difficulties had surfaced at previous private meetings with Murdoch, where Dean felt that Dubbins was making promises and threats that he simply could not deliver, owing to the autonomy of the NGA chapels (Dean, 2007:76). Interviewees confirmed that Dubbins felt that Dean was so unsupportive at this meeting, that she was tacitly siding with Murdoch.

This wariness of Dean and Dubbins for one another has been remarked upon by other scholars' commentating on the dispute (Gennard, 1990; Gennard and Bain, 1995; Cockburn, 1991; Richardson, 2003; Melvern, 1986; Bain, 1998). In seeking to explain this animosity some of these authors cite inter-union friction (Gennard, 1990; Gennard and Bain, 1995) others straightforward sexism (Cockburn, 1991), whereas a final group suggest craft and political tensions (Bain, 1998; Richardson, 2003; Melvern, 1986). Yet Interviewees, particularly those very close to the two protagonists, focused more on micro-political issues. A senior NGA figure commented that:

It wasn't that Dean was a woman, Dubbins had always got on fine with other women activists and officers in SOGAT and the NGA ... no they were just always uncomfortable with each other and there was never any trust between them. 
Other interviewees, including a number of women, also focused on Dean and Dubbins's very different personalities, rather than any gender based issues, in explaining their antagonism. As one interviewee stated they just always "rubbed each other up the wrong way".

\section{Micro-political divisions in SOGAT during the dispute}

In early September 1985 a 'dummy' copy of The Sun newspaper, which had been produced at the Wapping plant, was smuggled out and handed to the unions. The production of an actual newspaper was proof that the EETPU members working in Wapping were now running, not just installing, the presses. Interviewees and scholars (Gennard, 1988; 1990; Gennard and Bain, 1995; Bain, 1998; Melvern, 1986; Littleton, 1992; Richardson, 2003; Shawcross, 1992) agree that it was then that the print unions missed a golden opportunity to take strike action, which could have had a devastating effect on Murdoch's plans to relocate his London operations to Wapping. As one interviewee stated:

That was it. That was our great chance. If we had gone then we could have won. He was not ready to produce his papers without us, and we now know how financially stretched he was. I'm certain he'd have cut his losses and our people would have been in Wapping. (Blissett, 2014:164)

In his biography of Murdoch, Shawcross (1992) asserts that Murdoch was so financially exposed in the USA in 1985 that his companies could not have withstood the loss of revenue caused by an unofficial strike on The Sun and The News of the World for more than a few days (Shawcross, 1992: 334-337). This assertion is endorsed by Andrew Neill, then the editor of the Sunday Times (Neill 1997:154).

Union interviewees, whilst agreeing that in hindsight the decision not to take action in early September played a decisive role in their eventual defeat, are profoundly divided over why they did not do so. Those close to Dean are adamant that although legally prohibited from publically endorsing unofficial action, she had expected the News International chapels to walk out. Significantly, similar sentiments were also expressed by senior officers of the NGA. The News International SOGAT chapel officers contradict this view, stating that they were told 
that Dean wanted no action, until they had met with Murdoch, in late September 1985.

What is striking, from all the interviewees involved, was the consensus that no direct communication took place between the FoCs and Dean, about unofficial action. Such discussions were, after the passing of the 1982 Employment Act, fraught with legal dangers for the union ${ }^{11}$. However, as a former senior union officer who was 'involved' in a significant number of large unofficial strikes ${ }^{12}$, I know how important it is for local lay officers to be aware of the union's true view of the unofficial strike action. As interviewees from both sides concede, the deep distrust that existed between Dean and the News International FoCs meant that neither side would engage in a candid conversation over this issue. This led to the use of intermediaries, and subsequent confusion over Dean's 'real', as opposed to her 'public' view on unofficial action.

How great an influence this confusion had on the News International production chapel members' decision not to take unofficial strike action is not clear. Many interviewees pointed out that the News International chapels had regularly taken unofficial action previously without any form of approval from the SOGAT, NGA or NATSOPA General Secretaries. Yet, in this instance, the leadership of The Sun LCB chapel decided not to call for unofficial action, whilst the London Machine Branch (LMB) committee, which recommended taking an immediate 24 hour strike, was defeated at a chapel meeting by 520 votes to 306 .

Interviewees differ as to why the London Central Branch Sun chapel committee did not recommend immediate strike action and the LMB chapel meeting overturned their chapel officers' strike recommendation. They all agreed though that a proportion of the membership were uncertain as to the support they would receive from the national union if they took action and were then locked out or dismissed. These concerns were more important to some members than had been the case previously, because their employer now had the ability to produce a paper without them. Other members admitted that they refused to

\footnotetext{
${ }^{11}$ The 1982 Employment Act charges unions with publically repudiating unofficial action. If they do not do so they risk the imposition of heavy fines and claims for damages, if Court actions are brought against them by the employer.

12 The most notable of these were the various British Gas Service London Weighting unofficial strikes of the late 1990s and the 2003 unofficial strike by British Airways, Customer Service Staff.
} 
believe the evidence supplied to them because it came from RIRMA branch officers, whom they distrusted. This disbelief reflected not only occupational prejudices, but also the dysfunctional personal relationship, that had developed between many of the production chapels FoCs and the RIRMA branch officers. In the wake of these decisions by the larger SOGAT chapels, the NGA News International chapels followed suit and did not take unofficial action.

At the subsequent meeting with Murdoch at the end of September 1985 there seemed to be scope for reaching a settlement over the move of SOGAT and NGA members to Wapping. Murdoch stated that he wished 'in a spirit of unity' to reach an agreement with the print unions by Christmas over The London Post and the move of The Sun and the News of the World to Wapping (Bain, 1998:80; Gennard, 1990; Gennard and Bain, 1995, Richardson, 2003; Bain, 1998; Melvern, 1986; Dean, 2007; Blissett, 2014) However, after the meeting, News International produced a list of demands (dubbed by SOGAT FoCs as 'The serfs' charter'), which included no negotiations with chapels or branches, no closed shops, no industrial action, total flexibility, legally binding collective agreements, and the right of management to decide staffing levels, work methods, and whether new technology was to be introduced (Littleton, 1992: 68-69). In other words, total managerial control of all aspects of the labour process.

These demands were rejected by members of all the News International unions, including the EETPU. They stated, however, that they were prepared to negotiate greater job flexibility. On the $10^{\text {th }}$ December 1985 , the EETPU national union declared that they were prepared to accept News International's demands. The NGA, SOGAT and the AUEW then sought assurances from News International that their members' jobs were not under threat, and also presented the 1986 annual wage claim. News International rejected the claim and stated it would no longer negotiate with SOGAT, the NGA, or the AUEW. This was followed, on the $6^{\text {th }}$ January 1986 , by the company serving a six month notice of termination of all its collective agreements with the recognised unions.

On receiving the notice, SOGAT and the NGA chose to remain within the new employment legislation and instituted a strike ballot of their News International members. SOGAT members and NGA members 
both voted in favour of strike action, SOGAT by 3,534 to 52; the NGA by 843 to 117 . On the $23^{\text {rd }}$ January 1986 the unions met Murdoch again. He refused to move on any of the company's demands and made it clear there would be at least 4,000 redundancies.

At this time there was unanimity between the affected chapels, branches and union leaderships that official strikes now had to be declared. Whilst there was still simmering disagreement over who was responsible for the unions finding themselves in this position, there was unity over declaring an official strike. On the 24th January 1986, SOGAT, the NGA and the AUEW all declared the start of an official strike. The company responded on the 25th January by dismissing all of the strikers. In doing so the company was acting upon legal advice that, since the passing of the 1982 Employment Act, it could avoid paying the striking workers redundancy compensation if they dismissed all those taking part in strike action.

The senior officers and local lay officials of the print unions were united in their belief that in order to change Murdoch's decision to dismiss their membership and hire an alternative workforce, they had to disrupt News International's ability to publish and distribute its titles. Yet even at this stage of the dispute, another fissure opened between the SOGAT chapels and Dean. The disagreement centred on Dean's determination that the union's national officers would take over direct responsibility for all negotiations surrounding the dispute, a decision that antagonised the affected chapels and branches.

Discussions with News International, in the early months of 1986, made no progress. It also quickly became evident that the company had switched to using TNT, an Australian distribution company, to move all of its papers by road, rather than rail, to the wholesalers' distribution depots. This rendered ineffectual the support that SOGAT and the NGA had been promised by the rail unions. In order to counteract road distribution, SOGAT and the NGA nationally adopted two specific tactics, which were endorsed by the two unions national leaderships and the chapels and branches.

The first comprised a twenty-four hour picket of the Wapping site, organised by the chapels and well attended by the dismissed members. 
The aim was to stop or delay all TNT lorries exiting the company's production sites. This tactic built on the NGA's experience at Messenger Group Newspapers, where the Union's mass picket had, on a number of occasions, severely delayed deliveries from the Warrington site ${ }^{13}$. The unions reasoned that whereas these delays had only caused inconvenience to the Messenger Group, because they produced weekly titles, that similar disruption to News International's daily distribution could badly damage the company's finances.

Allied to this action SOGAT called on its members in the newspaper wholesalers to refuse to handle News International titles. This second element of the union's industrial action strategy seemed to be a powerful weapon. In January 1986 SOGAT possessed post-entry closed shops in all three of the largest wholesalers; John Menzies, W.H. Smiths and Surridge Dawson.

In the initial weeks of the industrial action the mass picketing had a considerable effect. TNT lorries were badly delayed, which meant that papers arrived at the wholesalers too late to be delivered with other newspapers to the newsagents. News International's revenue was badly affected and in late January 1986 a deeply concerned Rupert Murdoch spoke to the Home Secretary and the Prime Minister. He gained assurances that in future the Police would do all in their power to ensure that newspapers got out of Wapping on time (Neill, 1997; Shawcross, 1992).

In the weeks that followed the Metropolitan Police went to extraordinary lengths to ensure TNT vehicles exited the plant promptly. Adjacent roads were regularly sealed off, local residents were not allowed to leave or enter their homes at certain times, and TNT vehicles were allowed to flout traffic laws on a regular and systematic basis. In response the chapels and branches escalated the scale of the picketing and organised large demonstrations outside the plant. Hundreds, and on

\footnotetext{
${ }^{13}$ The 1983 Warrington Messenger dispute was triggered when the owner of Messenger Newspaper Group, Selim 'Eddie' Shah decided to staff new typesetting and production premises with non-union labour. The NGA members in his other small unionised sites took strike action and the NGA instructed all members not to handle any Messenger Newspaper copy or products. In addition the Union organised a secondary picket of the non-union sites. It was this secondary picket and the secondary industrial action that breached the 1980 and 1982 Employment Acts and led to the High Court imposing substantial fines on the NGA. (See Blissett 2014; Gennard 1995; Dickinson 1984; Geary, 1985)
} 
occasion thousands, of Metropolitan Police were deployed in full riot gear and there were numerous incidents of police, sometimes on horseback, baton charging picket lines and causing serious injuries.

The escalation of picketing, and the violent confrontations with the police, led to further internal tensions within SOGAT. Interviewees stated that, from the outset, Brenda Dean was concerned that the pickets were being controlled by the chapels and branches, whose leadership she viewed as "irresponsible and hot headed". Her doubts over allowing them to continue to control the picketing grew as the dispute continued, but she and her supporters were aware of the loyalty that many of the News International membership felt towards their chapels and officers. So whilst the divisions and arguments grew over picketing tactics, the control remained with the chapels and branches.

The mass picketing was overwhelming supported by dismissed News International SOGAT and NGA members. However, SOGAT's call for secondary action by wholesale distribution members received a less wholehearted response. In some areas such as London, Glasgow and Liverpool the secondary action was immediately effective, but in other areas the SOGAT wholesale branches failed to follow the NEC's instruction to 'black' News International titles.

Part of the reason for this failure, as Richardson (2003:100) has highlighted, revolved around the organisational weakness of SOGAT's post-entry closed shops in a number of the wholesalers' depots. This organisational frailty had previously been highlighted by the national newspapers National Officer, Bill Miles at the 1983 BDC. Yet the problem had not been remedied by the start of the dispute in January 1986. Opponents of Dean, when interviewed, claim that part of the reason for this failure was related to Dean and her supporters not wishing to upset branch secretaries who had supported her in the General Secretary election.

Interviewees also highlighted another major problem that senior SOGAT officers faced in persuading the wholesale membership to refuse to handle News International titles. This difficulty centred around the reluctance of provincial branch officers to even call on their members in the wholesalers to undertake secondary action. The causes of this 
internal conflict between the London newspaper chapels and their provincial counterparts have been the subject of analysis by a number of authors (Richardson, 2003; Bain, 1998; Gennard and Bain, 1995) who have drawn attention to the long-standing occupational and regional divisions that existed between the former NATSOPA London newspaper activists and the provincial, previously NUPBPW, branch officers. These authors also highlight the dangers that SOGAT's wholesale members faced in 'blacking' News International titles, after changes had been made to employment legislation in the early 1980s, which made the secondary industrial action unlawful (Richardson, 2003; Bain, 1998; Gennard and Bain, 1995).

However, while this analysis is in part supported by interviewees, many of them placed greater emphasis on the rancorous personal relationships that existed between London newspaper chapel officers, and their regional counterparts. This, both sides confirmed, was evident at SOGAT's NEC and Biennial Delegate Conference, where they engaged in frequent public and private arguments. It was also the contention of London branch and chapel officers, and a number of the provincial branch secretaries that this deep-seated personal animosity contributed greatly to the "very lacklustre" efforts of many provincial branches to get their members to 'black' News International titles.

These divisions proved to be crucial in undermining SOGAT's plan to disrupt the wholesalers' supply of News International papers to the retailers. A plan, which if it had been successful, as it broadly was in Liverpool and Glasgow, could have undermined Murdoch's alternative distribution strategy. In Liverpool and Glasgow the SOGAT wholesale members were not only well organised, but had branch and chapel officers who generally enjoyed a cordial personal relationship with the News International FoC's.

The problems that the SOGAT leadership faced, in getting its wholesale members to 'black' News International titles, were exacerbated early in 1986 by the High Court's ruling that their secondary action was unlawful (Gennard and Bain 1995:609). In response, in line with their national policies, both SOGAT and the NGA refused to withdraw their instructions to members to take secondary action. As a consequence SOGAT was again taken to the High Court, where on $10^{\text {th }}$ February 1986 it was found 
to be in contempt of court, resulting in a $£ 25,000$ fine and the sequestration of all its assets, including the considerable funds and properties held by their branches. The High Court further ruled that the union could only come out of sequestration if it purged its contempt of court (Gennard and Bain 1995:610).

It was at this stage that Brenda Dean took the decision that, unlike the NGA or the National Union of Mineworkers (NUM) ${ }^{14}$ during their periods of sequestration, SOGAT would fully co-operate with the sequestrators. This decision incensed many SOGAT officers and activists, particularly those from News International who were outraged that the Union should in any way help the sequestrators. Many of them believed that Dean's actions were "very fishy" and were driven by a lack of commitment to the strike. This conspiratorial view of Dean's actions is dismissed by her supporters, who point to the manner in which she skilfully articulated the sacked members' case, particularly via the media. The reason, they state, that Dean and the NEC agreed to co-operate was in order to appear as a reasonable law-abiding trade union, which had been placed in contempt of court by unjust laws (Gennard and Bain, 1995; Dean, 2007).

The fissures within SOGAT over how to prosecute the dispute now started to widen dramatically. The Union split into two camps, with the London branches and a small Broad Left ${ }^{15}$ factional group on one side, and the General Secretary along with the majority of the NEC and many provincial branches on the other. Gennard and Bain (1995); Richardson (2003) and Bain (1998) all attribute this split to a mixture of geographical, occupational and political differences. Interviewees' evidence strongly suggests that whereas there is some substance to these assertions, micro-political factors also played a considerable part in shaping these divisions. This was especially the case in London where 'moderate' SOGAT chapels and branches, which were privately highly critical of the News International chapels, would not openly criticise, let alone withdraw support, from the dispute, owing to loyalty to friends and relatives who were involved.

\footnotetext{
${ }^{14}$ The National Union of Mineworkers had its assets sequestrated during their 1984-1985 national strike. The NGA had its assets sequestrated in 1983 during the Messenger Group Newspaper dispute (See Dickinson, 1984; Gennard 1990; Winterton and Winterton 1989; Hain, 1986).

${ }^{15}$ The SOGAT Broad Left was a left of centre internal political factional group made up of SOGAT officers and activists.
} 
The News International chapels pressed for an escalation of the secondary action, including a stoppage on all the national newspapers and, if necessary, a national strike of all SOGAT members. A smaller element, from the London branches, also wished to take direct physical action against News International's production premises ${ }^{16}$. Taking the opposite view, Dean and her supporters favoured staying, wherever possible, within the law. This, they claimed, was in order to protect the Union's ability to function for all its members, many of whom were not involved in the dispute. To this end, they were particularly concerned to reverse the High Court's decision that the sequestrators could seize the considerable funds held by the SOGAT branches.

By March 1986 these internal divisions had widened. Sequestration had meant that all the national union accounts were frozen and officers' cars were impounded. These actions made the core activities of the union, specifically full-time and lay officers conducting negotiations and representing members at disciplinary and grievance hearings, extremely problematic. The decision to co-operate with the sequestrators also meant there was no illicit cash held by the Union, or its supporters, to pay for any of SOGAT's operations.

The effects of the sequestration led the NEC to call a meeting of all branch secretaries on the $14^{\text {th }}$ April 1986 to discuss how to respond. There was, participants' recall, an impassioned debate, with many of the branch secretaries from the provinces calling for the 'contempt of court' to be purged so that the union could regain the use of its assets and function normally. On the other hand, the London branch secretaries accused those seeking to purge the Union's contempt of court of betraying the members in dispute. The majority of the branch secretaries eventually decided to support Dean's position, which was that the Union should await the outcome of its legal challenge to the sequestration of SOGAT branch funds.

At the subsequent NEC on the $21^{\text {st }}$ April there was a further delay in deciding whether to purge the Union's contempt of court. Interviewees from both sides stated that the majority of the NEC was, by then, in

\footnotetext{
${ }^{16}$ These plans revolved around a physical attack on the Wapping printing plant. Interviews and further research suggest these were serious plans, involving third parties, who had the knowledge and equipment necessary to cause serious damage to the News International premises (see Blissett; 2014).
} 
favour of this course of action. However a number of delegates, particularly those from Scotland, wished to delay a decision until Scottish News International members, who had marched all the way from Kinning Park, Glasgow, arrived in Wapping on $3^{\text {rd }}$ May 1986. This suggestion held sway and there was a major rally and demonstration at Wapping on the $3^{\text {rd }}$ May. The event, which was attended by over 12,000 people, was met by what one interviewee described as a "frightening degree of force" by the police. Over 250 demonstrators were injured when mounted police staged a series of charges into the demonstrators.

On $6^{\text {th }}$ May 1986 the branch secretaries, and subsequently the NEC, both met again. The Court of Appeal had by this time ruled that some 80 SOGAT branches funds were separate from the assets of the national union and they were therefore released from sequestration. However, the other branches funds remained sequestrated (Gennard and Bain, 1995; Blissett, 2014). At their meeting the branch secretaries and subsequently the NEC (by 22 votes to 11) agreed to purge their contempt of court. The majority opinion, led by Dean and her senior officers, was that the 'blacking' was not working outside of a few major cities and it was nonsensical for the Union to be sequestrated over a policy that was ineffective. Unsurprisingly, the London delegates were incensed, with one describing the decision as a "total betrayal". Two days later, after the withdrawal of the instruction to all members not to handle News International papers, SOGAT's funds were released by the High Court (Gennard and Bain, 1995; Blissett, 2014; Dean, 2007).

The abandonment of the secondary action caused SOGAT's London District Committee, which contained all the London branches, to register its "disgust and abhorrence" at the actions of the NEC and the General Secretary. It also called upon Dean to explain the NEC's decision at a meeting of News International members on $19^{\text {th }}$ May 1986. By this stage the relationship between the London branches and the General Secretary had deteriorated to such an extent that they both believed that the other's actions were undermining the possibility of resolving the dispute. Those close to Dean alleged that a number of the London activists were, by this stage, unrealistic in their expectations of how the dispute could be resolved. They also asserted that the News International chapels were also actively seeking to remove the General 
Secretary from office. On the other side of the argument, FoCs and activists from the London branches strongly believed that the national leadership had betrayed them by calling off the secondary action.

The visceral and highly personal nature of SOGAT's internal conflict was to be heightened by what transpired at the meeting of News International members on $19^{\text {th }}$ May 1986. Prior to the meeting, senior national officers advised Dean that, owing to the anger of the News International members, it would be unwise for her to attend. Dean though was adamant; she was the Union's senior officer and she would attend. The meeting was extremely stormy: jeers and catcalls punctuated Dean's speech, and questions to her were relentlessly hostile with many deeply personal criticisms thrown in. One SOGAT London official who was present commented:

'The only thing that I was thankful for was that there was no violence. Apart from that the meeting was totally bloody awful' (Blissett 2014:181).

At the end of the meeting a resolution was overwhelmingly carried, demanding the dispute was escalated and condemning the NEC's decision to call off the secondary action.

Following the meeting the personal rancour and division inside SOGAT escalated still further. Those who supported the General Secretary now believed that the conduct of the chapel officers and pickets meant that Murdoch would never reinstate any of the sacked workers. Therefore they believed that the Union should now negotiate an acceptable compensatory settlement. As they stated in their interviews, by this time SOGAT needed to focus on dealing with numerous other employers which were exploiting SOGAT's weakened industrial and financial position. Specifically, many employers had become sufficiently emboldened, during the dispute, to attack their closed shop agreements with SOGAT, whilst introducing technology and working practices which resulted in a huge number of redundancies.

According to her supporters, it was these concerns that led Dean to engage in secret direct talks with Murdoch and other News International directors, without the knowledge of the News International FoCs or the NGA. Unsurprisingly, the London branches soon learnt of these 
meetings and were incandescent with rage. This led them to make further accusations of treachery and the undermining of the Union's constitutional structure. When it became aware of the secret meeting, the NGA demanded that official discussions between both print unions and Murdoch were scheduled. Murdoch agreed and a meeting took place at the end of May. At that meeting Murdoch, whose News International titles were suffering from significant falls in circulation and advertising revenue, made an offer that encompassed; redundancy pay, the lifting of the bar on strikers working at Wapping, a review in a year's time of union recognition, and the 'gift' of the Grays Inn Road premises and printing equipment. He also offered to lift all legal action, but insisted on a response from the unions within one week.

The NGA recommended its members reject the offer, with News International members to vote via a ballot conducted by the chapels and branches. SOGAT acted quite differently. The NEC decided to issue a postal ballot sent directly to the members involved. Enclosed with the ballot paper was a five page letter from Dean which, without specifically recommending acceptance, encouraged members to vote to accept the offer. Reflecting upon this decision, a number of senior officers candidly admitted that the postal ballot was undertaken in order to bypass the influence of the FoCs.

This decision further exacerbated the divisions between SOGAT's national leadership and the London branches, not just over the conduct of the News International strike, but also the way in which policy making was being centralised. The London branches believed that the NEC's conduct of the News International ballot was contrary to the Union's rules. Interviewees also recalled that they felt that Dean was now seeking to remove policy-making authority from the chapels and branches. So exercised were they by this belief that the LMB sought a High Court injunction to stop the postal ballot. The application failed on what the High Court described as 'the balance of convenience' for the Union. The ballot resulted in SOGAT members rejecting the offer by 2081 votes to 1415 . The NGA membership also voted, by 648 to 165 , to reject the offer.

Soon after the rejection of Murdoch's offer, SOGAT's Biennial Conference met in June 1986. Prior to its opening, efforts were made to 
avoid a very public confrontation over the conduct of the dispute. This proved to be a very difficult set of internal negotiations which were undertaken by senior SOGAT newspaper officers and NEC members. In her opening address, and before any deal was reached, Dean decided to openly attack what she called 'wreckers' in SOGAT. Many interviewees' stated that her speech was so well received by a substantial majority of delegates, that those brokering a deal were assisted in reaching an agreement with the London branches. The agreement entailed the NEC agreeing to assist in increasing the number of pickets at Wapping and giving an undertaking that any negotiated resolution to the dispute would involve jobs and recognition for the sacked workers. In return the London branches agreed to support the NEC's express position that the Union would do everything possible to avoid sequestration. The deal resulted in a relatively peaceful conference, with the only major argument occurring over the LMB branch's motion calling for the resumption of blacking of News International titles, which was opposed by the NEC, and then overwhelmingly defeated.

Immediately after the SOGAT BDC there was the increase in picketing at News International. The company took further legal action which resulted in limitations being placed upon picketing and demonstrations at both News International and TNT sites (Blissett, 2014; Bain, 1998). At this time Neill, (1997) states that News International directors still believed they could lose the dispute, which led Murdoch to make what he described as 'his best and last offer' (Neill, 1997:187). This was similar to the previous offer, but it did contain the acceptance that SOGAT and the NGA could represent members individually within Wapping. The offer was again rejected by the members of all three unions; with SOGAT members voting 2372 - 960 against the offer, a sizeable increase in the no vote compared to the previous ballot.

After seven months in dispute, and with no sign of a settlement being negotiated that would be acceptable to the members concerned, SOGAT faced mounting financial problems. Although efforts had been made to gain financial support from British and overseas trade unions, the Union and its London branches and chapels were incurring huge costs in running the dispute, which when allied to rapidly reducing 
income levels, led to a financial crisis. Inside the NGA the financial position was slightly better, owing to the smaller number of members involved in the dispute and the larger financial income that the Union generated from its relatively high subscription charges. However, the financial costs incurred during the Messenger strike, when added to the expenditure on the News International dispute and falling membership income, also meant that the NGA was starting to experience financial difficulties.

As all efforts to negotiate a settlement in the autumn of 1986 failed, SOGAT's monetary problems grew worse. Those branches with large numbers of members in dispute were in acute financial difficulties as they continued to support their dismissed members. The LCB had spent $£ 500,000$ on the dispute, whilst the RIRMA branch had paid out over $£ 750,000$, and SOGAT nationally had spent in excess of $£ 3,000,000$. The branches and national union were rapidly approaching a position in which they could not assist the strikers. In response the NEC proposed a temporary six month levy on members of 58p week. The increase was put to the members, and although the SOGAT Journal campaigned for acceptance, it was rejected by 51,187 votes to 44,265 . In the recollections of many officers and NEC members, including those from London, this was the point when they knew that it would not be feasible to continue the dispute. As a former senior SOGAT officer stated "when the vote came in I knew the game was up".

Shortly after the ballot result was declared, News International sought to exploit SOGAT's weak financial position (Neill, 1997) by issuing writs for contempt of court against the print unions, in relation to their continuing organisation of mass pickets. After advice from solicitors that the action may well succeed, Dean called an emergency NEC on $5^{\text {th }}$ February 1987, where she advised that to continue the dispute would result in sequestration, which would be in contravention of BDC policy. Her recommendation was that the NEC should terminate the strike, without a ballot of the members involved.

Contact had been made with News International, which stated that it would implement its previous offer and withdraw legal action, if it received a letter from SOGAT terminating the industrial action and all boycotts, within 24 hours. The NEC then voted 23-9 to end the News 
International dispute. The next day, the NGA NC met and agreed, by 27 votes to 5, that it should not pursue the News International dispute alone, and agreed to end the industrial action.

\section{Micro-political divisions between Dean and Dubbins, during the dispute}

The wariness and lack of trust that had characterised the relationship between Dean and Dubbins before the News International dispute worsened considerably during its course. Indeed, by its end, they were barely on speaking terms. This was in marked contrast to the NGA's 1983 Messenger Newspaper dispute, where often bitter historical occupational animosities between the NGA and SOGAT, were side-lined as Bill Keys worked hard to assist the NGA. In doing so he formed a very close working relationship with Tony Dubbins (then NGA Assistant General Secretary) and the General Secretary, Joe Wade (see Blissett, 2014; Dickinson, 1984).

As NGA interviewees stated, from the outset of the News International dispute Dubbins believed that Dean, whom he viewed as being too close to Murdoch, would be engaging in clandestine talks with News International. These fears solidified a few weeks into the dispute when he learnt that Dean was speaking privately to News International executives. After these reports, he and other senior NGA officers decided to keep private all the NGA's plans over how they were to prosecute the dispute. Co-operation with SOGAT was kept to a minimum, and moves to apply pressure to Murdoch through various forms of secondary action and political lobbying were not discussed, let alone agreed, with SOGAT.

The most striking example of this refusal to share information with SOGAT surrounds the plan, proposed by a group of senior NGA lay officers, to enter and occupy the News International Kinning Park site. The arrangements were all in place when, by a narrow majority, the NGA NC rejected the plan, on the grounds that it was too dangerous for those members involved. Significantly SOGAT was not involved or even informed, at any stage, in the planning of this action.

Interviewees close to Dubbins stated that he was also convinced, from early in the dispute, that Dean would 'eventually do a dodgy deal' with 
Murdoch behind the NGA's back and then end SOGAT's participation in the dispute. This would leave the NGA with members still on strike, but with next to no ability to reach any form of negotiated settlement. In the aftermath of the Messenger Newspaper Group dispute, where the NGA incurred huge fines for engaging in secondary action, this was a very substantial concern. In order to counteract this possibility, Dubbins convinced a majority of his NC that they must not continue with the strike, if SOGAT were ever formally to withdraw support for the action.

The suspicion that emanated from the NGA towards SOGAT was reciprocated by Dean and her supporters. She believed (Dean, 2007:133) that Dubbins was constantly attempting to undermine her in meetings with News International and that he deliberately fostered antipathy towards her among her own News International FoC's and branch officers. According to those close to Brenda Dean this then led her to take the decision to pursue secret talks with Murdoch. An action which, when discovered by the NGA, led the unions into an ever accelerating cycle of mutual distrust and recrimination.

So poor had inter-union relations become by February 1987, that when the SOGAT NEC voted to end the dispute, without consulting the members involved, it did so without seeking the opinion of the NGA, let alone its agreement. Interviewees present at the NGA NC, which took place the next day, made it clear that Dubbins stated that Dean had betrayed her own and the NGA's members, but that they, as the minority union, could not continue with the dispute alone. The majority of the NC backed his position and the NGA terminated the dispute with News International.

These decisions were met with considerable anger by those in dispute. A number of SOGAT members continued to picket Wapping unofficially, until they finally withdrew after the SOGAT London District Council met in February 1987 and passed a motion praising the strikers for their determination and loyalty, but also advising them to apply for their compensation packages. This brought to a close the dispute with both unions derecognised by News International and all 5,500 of their members dismissed. 


\section{Conclusion}

The loss of the News International dispute proved to be a devastating blow to the NGA and SOGAT's organisational and industrial strength, not only in the national newspapers, but across the whole printing industry. Soon after the dispute both unions were derecognised by the majority of national newspaper publishers, who also moved their production premises, introduced new digital technology, and shed thousands of staff (Blissett, 2014; Gennard and Bain, 1995) Even in the general print industry, where the unions generally were not derecognised, both unions suffered massive membership losses as digital technology and new working practices were introduced.

These membership losses, allied to the vast amounts of money they had spent in financing the dispute and in paying court fines, finally drove the two unions into an acrimonious merger. This in turn resulted in a bitter leadership battle between Dean and Dubbins for the post of Graphical Paper and Media Union (GPMU) General Secretary, which Dubbins won. This was thanks, in no small part, to the support of SOGAT national newspaper members. Brenda Dean then left the union, which itself was forced, by declining membership, into a further merger with Amicus (previously known as the Amalgamated Engineering and Electrical Union) in 2004, prior to another amalgamation with the Transport and General Workers Union (T\&GWU) in 2007 to form Unite the Union.

In considering the different explanations that authors have put forward for the unions defeat, this article has demonstrated that the simple assertion that the dispute was unwinnable, whatever tactics the unions had adopted, is flawed (Gennard, 1990; Gennard and Bain, 1995). Interviews with managers for this article and the accounts of Neill, (1997) and Shawcross, (1992), clearly demonstrate how Murdoch would have struggled to cope with any serious disruption to his major income generators, his British newspapers, in the autumn of 1985 . This, as all the accounts confirm, was owing to how financially stretched Rupert Murdoch had become when purchasing Twentieth Century Fox. 
If unofficial strike action had been taken at that time, management interviewees have confirmed that concessions, such as the movement of staff from Grays Inn Road and Bouverie Street to Wapping, and the continued recognition of SOGAT and the NGA at Wapping, would have been offered by News International. This is not to say that large-scale job losses and the introduction of new technology would not have occurred, but that the methods of adopting this technology and changes to working practices would have been similar to that adopted by News Limited in Australia (see Blissett, 2014). Here such changes were negotiated with the Printing Kindred Industries Union (PKIU), which remained recognised at the new production facilities, and which negotiated large voluntary severance packages for redundant members who had worked in the former pre-production and production areas.

Although the hostile legislative climate, which the unions faced during the mid 1980s, made taking effective unofficial or secondary action difficult, it was not impossible. The well organised secondary action, by wholesale SOGAT branches in Liverpool, Glasgow and London, was effective. News International management interviewees confirmed that if this action had been repeated across the whole country, then the company would have been forced to negotiate a settlement, because of the impact that such a boycott would have had on sales. They also confirmed that News International could not have waited for its High Court action against SOGAT to be heard, and then implemented, if none of the newspapers were arriving at retailers. The reason being, that at this time, News Limited globally simply could not have afforded for its British sales to be badly disrupted for more than a few days.

This argument is further strengthened by the success of other unions in taking effective unofficial strike action in the early 2000s ${ }^{17}$ (Blissett, 2014). In these cases the detrimental impact on the respective company's operations was so severe that settlements were negotiated with the unions prior to the companies pursuing, what would almost certainly have been, successful court action. This was the case at a time when the legislative penalties that could have been imposed on the

\footnotetext{
${ }^{17}$ The GMB, TGWU and Manufacturing, Science and Finance Union (MSF) members working for British Airways as Passenger Service agents took highly effective unofficial strike action for 48 hours in August 2003, whilst GMB British Gas London Engineers also took unofficial strike action which resulted in a settlement of two separate London Weighting disputes in the early 2000's.
} 
unions for taking secondary action were even more draconian than in the mid-1980s.

Why the unions did not take unofficial action at News International in the autumn of 1985 and why the call for the 'blacking' of News International titles, was not heeded across the country, has been another central theme of this article. A number of authors (Richardson, 2003; Cockburn, 1991; Bain, 1998) have argued that divisions and organisational weaknesses within SOGAT, and tensions between the NGA and SOGAT, were to blame for the failure to take effective unofficial and secondary action, which if pursued, could have led to a more successful conclusion to their dispute. The reason for this failure, according to Bain and Richardson, was the political, occupational, and geographical divisions that beset particularly SOGAT. Cockburn (1991) on the other hand focuses on gender divisions within, and between, the unions as a central cause for the lack of effective action.

The evidence outlined here supports the view that the failure to take unofficial action in the autumn of 1985, and then to implement effective 'blacking' of News International titles by wholesale members, was decisive in the unions' defeat. However, it does not support the assertion that occupational, political, geographical or even gender divisions were the primary reasons why these forms of industrial action were not pursued or nationally implemented. Instead, what has been argued is the manner in which the profoundly dysfunctional micro-political relationship that existed between Brenda Dean (along with her NEC supporters) and the News International lay officers, undermined the trust and cohesion that is crucial if a union is to effectively engage in 'unlawful' unofficial or secondary action. It has also shown that the poor personal relationship between Dean and Tony Dubbins meant that they singularly failed to work together in a manner that was needed if their two unions were to be even partially successful in this dispute.

In the autumn of 1985, the News International production chapels FoCs failed to heed the warnings of RIRMA branch officers, in part, because of the micro-political divisions that existed between them. This failure was then disastrously compounded by Brenda Dean, who, having rightly believed the RIRMA branch intelligence about News International's plans for Wapping, then laid too much trust in the assurances she was 
given by Rupert Murdoch, because of her respect for him. A respect, which Dean (2007:58-65) and interviewees confirmed, was itself influenced by her deep loathing of his then rival, Robert Maxwell.

For all of these various micro-political reasons the first and best opportunity the unions had of gaining at least a partial success, in what proved to be a cataclysmic defeat, was lost. When a further, lesser, opportunity presented itself during the official dispute to extract at least some semblance of a 'reasonable' settlement, via a nationwide 'blacking' of News International titles, it too was squandered. The reason for the spurning of this opportunity was also, in large part, attributable to micropolitical divisions that existed within SOGAT. Schisms which left them fatally divided, and bound for a devastating defeat.

\section{Bibliography}

Bain, P. (1998). 'The 1986-7 News International Dispute: Was the Workers' Defeat Inevitable?' Historical Studies in Industrial Relations. Issue 5, 1998: 73-105.

Blissett, E. (2014). Inside the Unions: A comparative analysis of policymaking in Australian and British printing and telecommunication trade unions. Bern and Oxford: Peter Lang

Cockburn, C. (1991). Brothers - Male Dominance and Technological Change 2nd edition. London: Pluto Press.

Cohen, S. (2006). Ramparts of Resistance: Why Workers Lost Their Power And How To Get It Back. London: Pluto Press.

Dean, B. (2007). Hot Mettle - SOGAT, Murdoch and Me. London: Methuen Publishing Limited.

Dickenson, M. (1984). To Break a Union - The Messenger, The State and the NGA. Manchester: Booklist limited.

Dawson, T (2010). 'Out of Sight, Out of Pocket: Women's Invisibility in the British Printing Industry and Its Effect on the Gender Pay Gap', Historical Studies in Industrial Relations. 29/30, 2010: 61-98.

Geary, R. (1985). Policing Industrial Disputes: 1893 to 1985. Cambridge: 
Cambridge University Press.

Gennard, J. (1990). A History of the National Graphical Association. London: Unwin Hyman Limited.

Gennard, J. and Bain, P. (1995). A History of the Society of Graphical and Allied Trades. London: Routledge.

Gennard, J. and Haywood, G. (2008) A History of the Graphical, Paper and Media Union. London: Unite the Union.

Hammond, E. (1992) Maverick: The Life of a Union Rebel. London:

Weidenfeld and Nicolson

Littleton, S. (1992). The Wapping Dispute. Avebury: Aldershot.

Melvern, L. (1986). The End of the Street. London: Methuen.

Neill, A. (1996). Full Disclosure. London: Macmillan.

Richardson, M. (2003). Leadership and Mobilisation: 'SOGAT in the 1986-87 News International Dispute' Historical Studies in Industrial Relations, Issue 15 Spring 2003: 73-93.

Shawcross, W. (1992). Rupert Murdoch - Ringmaster of the Information Circus. Basingstoke and Oxford: Pan Books.

\section{Printing unions journals and reports}

Unite Journal

Amicus Journal

GPMU Journal

SOGAT Journals

NGA Journal
$2008-2016$

$2005-2008$

$1992-2005$

$1967-1992$

$1973-1992$ 
GPMU Biennial Conference Reports $1992-2005$

NGA Biennial Conference Reports 1976 - 1991

SOGAT Biennial Conference Reports $\quad 1978-1991$

\section{List of participants}

In order to protect the identities of participants, which was guaranteed prior to interview, the following list does not identify contributors by name or union. It does however indicate the post the interviewee held.

Position in union

Number of interviewees

General Secretaries

National Presidents

National Officers

National Executive/Council Members

Regional Officers

Branch Secretaries

FoCs/MoCs

Other branch and chapel officers

Lay members

\section{Other interviewees}

News International managers 2

Other national newspaper managers 2 